\title{
UNDERSTANDING OF ISLAMIC STUDIESTHROUGH SHARIA ECONOMICS PERSPECTIVE IN INDONESIA
}

\author{
Hendri Hermawan Adinugraha, Ali Muhtarom \\ Faculty of Islamic Economic and Business, IAIN Pekalongan \\ E-mail: hendri.hermawan@iainpekalongan.ac.id, \\ ali.muhtarom@iainpekalongan.ac.id
}

\begin{abstract}
The existence of religions now required to be actively involved in solving the problems facing by mankind. One of the problems faced is the interaction with the modern economy. One of the approaches that can be developed for discussion of Islamic studies is Sharia Economics perspective. This research aims to describe the implementation of Sharia Economics perspective in order to understand Islamic studies. Research methods in this research use literature research from both national and international journals and books related to the topic. Ideally, the Sharia Economics approach should be integrative and interdisciplinary. Integrative method seeks to combine the revelation and $r a$ 'y in economic studies to understand Islam from the economic aspect. While the method of interdisciplinary attempt to approach it with a wide range of disciplines such as economics, politics, law, history, so that produce a comprehensive study and relevant to the happening facts/phenomena.
\end{abstract}

Keyword: Islamic studies, Sharia Economics, integrative- interdisciplinary

\section{INTRODUCTION}

Allah creates human in this world as khaleefah (Caliph), it is described in the AlQur'an, it means: And [mention, O Muhammad], when your Lord said to the angels, "Indeed, I will make upon the earth a successive authority." They said, "Will You place upon it one who causes corruption therein and shed blood, while we declare Your praise and sanctify You?" Allah said, "Indeed, I know that which you do not know"(Qur'an, 2: 30).

The verse explains that mankind as khaleefah (caliph) have a responsibility for the prosperity of the earth.Humans are required to have the ability to grow and develop into insānkämil who has a good potential. The process of growing and developing to achieve those goals is called education. The most important study is education of religion. In Indonesia Islamic education has been going on for a long time and is developing, beginning with informal education through lectures on the surrounding community (Daulay and Tobroni, 2017).

The existence of religions now required to be actively involved in solving the problems facing by mankind. Religion is not only used as the identity of one's beliefs, 
but religion also required to be able to answer increasingly complex human problems. For an example the problem of human behavior on the interactions and transactions in the economy increasingly modern where the practice which may not occur at the time of the Prophet, for example; electronic commerce (e-commerce) transactions. Electronic commerce, according to Turban, King, Lee, burrows, and Turban are purchasing, selling, transporting or trading the data, goods or services by using internet and intranets (Turban, et all, 2015).

In another word e-commerce is a process of buying, selling, marketing the goods and services by electronic system such as internet or television, web site or other computer networks. This problem can be answered using a normative theological approach comes with understanding of religion that uses another approach that is operationally conceptually can provide answers to the problems that arise such as social science approach like economics science. This is strengthened by theory reviews of discourse analysis proposed by NormanFairclough (1995), he stated that science is inherently a part influenced by the social structure and are produced in social interaction.

Islam can be understood through various dimensions. In its development, not a few problems of Muslims who can studied through Sharia Economics approach, thus all the Sharia Economics practices can be used as a reference in solving the problems of the modern economy. In society, in economic terms more commonly understood as everything related to the material and wealth. In the reality of modern society, the economy serves as an indicator to assess the success of an individual. In order of statehood, economy even become the main indicator that determines a country classified as Developed Countries, Developing or Least Developed Countries. This further reinforces the meaning of the term economics associated with the material and wealth (Byarwati, 2013). While the Sharia Economics, economic behavior has implications for ethics, morality and other normative values have a prominent place so that in the development of his theory, economics is always upholds Sharia aspects of normative values (Hoetoro, 2007).

Based on the above, religion as a religious belief system by the mankind can be studied through a variety of approaches. One approach that can be developed for Islamic study was a social approach by Sharia Economics. The fact of the economic phenomenon that always changes arouse the interest of the authors to discuss the implementation of Sharia Economics perspectives for understanding Islamic studies.

\section{The Discipline of Islamic Studies}

Islamic studies are also called dirāsah islamiyah, the emergence of Islamic studies actually been preceded by the extraordinary attention to the disciplines of religion that occurred in the nineteenth century in the Western world. The attention is marked with the publication of various works in the field of religion, such as: books of Introduction to the science of religion by F. Max Muller from Germany (1873); Cernelis P. Tiele (16301902), P.D. Chantepie de la saussay (1848-1920) fromNetherlands. In the UK, appears Religious Science figure such as E. B. Taylor (1838-1919). In France the figure appears 
Lucian Levy Bruhl (1857-1939), Louis Massignon (d. 1958). America also gave rise to figures like William James (1842-1910) is known for her work The Varieties of Religious Experience (1902). Eastern Europe featuring Bronislaw Malinowski (1884-1942) from Poland, ElaideMircea from Romania. They were most known names in the world of religious knowledge at the time (Rokhzi, 2015).

Besides in the West, Asia also began to appear some figures Religious Science. In Japan appeared J. Takakusu credited with introducing "Buddhism" at the end of the nineteenth century and T. Suzuki with a series scientific work on "Zen Buddhism". India emerged as a pundit S Radhakrishnan Religious Science and philosophy of India, D. Moses Granaprakasam, Religious Truth late relations between Religions (1950), and PD Devanadan, author of The Gospel and Renascent Hinduism, which was published in London in 1959 (Sumardi, 1982).

In contrast to the Western and Asia, the study of theology in the Muslim world has been a long time coming. In the world of Islam known figures in various disciplines in the second and fourth century of Hijriyah. In the field of jurisprudence (law) known figures such as Abu Hanifah, As-Shafi, Malik, and Ahmad binHanbal. In the field of Tafsirscience known figures such as Al-Thabary, IbnKatsir, Al-Zamahsyari, and so forth.In the nineteenth century emerging figures such as Muhammad Abduh, RasyidRida, and in the twentieth century came other figures like Mustafa al-Maraghy, author of Tafsir al-Maraghy. In the field of theology emerged the great figures of the various sects: Khawarij, Murji'ah, Syi'ah, Asy'ariyah, andMu'tazilah. The author of this field, among others; al-Qadi Abdul Jabbar, author of al-Mughny and Sharh al-Usul al-Khamsah (d. $415 \mathrm{H}$ ). Sufism expressed in figures such as Al-Qusyairi famous with his book Ar-Risalah al-Qusyairiyah (d. 456), Abu Nasr al-Sarraj al-Thusy (d. $378 \mathrm{H}$ ), the author of al-Luma', Al- Kalabadzi, author of At-Ta'arrufMadzhab li Ahl al-Tashawwuf, Abdul Qadir alJailany, author of book ofSirr al-Asrar, al-Fath al-Rabbaniy, and many others (Praja, 2002).

The existence of religious knowledge factually not be denied, but among the experts, there are still differences of opinion regarding"whether Islamic studies can put into the field of science or not?", it arises due to the differences in the nature and characteristics between science and religion. Studies on this subject often raised by Islamic thinkers today. For the example, Amin Abdullah suggests that the source of the difficulty of developing the scope of the study area study of Islam is rooted in a clerical limited ability to distinguish between Islamic studies normative and historically. At the normative level, the study of Islam much burdened by religious missions that are impartial, romantic, and apologists, so the level of content analysis, critical, methodological, historical, and empirical, mainly in studying texts or manuscripts product of history is less highlighted, except in certain environmental researchers are still very limited. Therefore, at the level of historical Islam is said to be highly relevant disciplines (Abdullah, 1996).

Differences in viewing Islam that can make a difference in explaining Islam itself.From the normative perspectives, Islam is the religion which contains the Lord's 
teachings regarding faith and mu'amalah. Whereas, from the historical or sociological perspectives, Islam emerged as a discipline (Islamic Studies). Thus, the study of Islam can be interpreted as an attempt to study in depth and systematic about things related to religion, good teachings, history and practices of implementation factually in everyday life (Anwar and Badruzzaman, 2009).Meanwhile, Islamic science as presented by Sayyed Husain Nasr (1995)is a science developed by the Muslims since the second century of Hijriyah, such as medicine, astronomy, and so forth. Thus, it can be said that the scope of Islamic sciences cover a wide range of modern knowledge that build on Islamic values.

Islamic studies are formulated knowledge of the teachings of Islam practiced in history and human life. Meanwhile, religious knowledge is knowledge that is entirely drawn from the teachings of Allah and His Messenger purely without being influenced by history, such as the doctrine of the faith, worship, reading the Koran and morals (Rokhzi, 2015). Religious-oriented education as the foundation or foundation of its development, it will become easier and faster to advance in human resource development (Rahman, et all, 2017).

Based on the explanation above, the Islamic studies as a distinct discipline is closely related to the issue of methods and approaches that will be used. One of the ways is using a Sharia Economics approach to understand part of Islamic study.

\section{Sharia Economics Method in Islamic Studies in Indonesia}

In 1998 in Indonesia, the Islamic economic movement began to flare up and become a pioneer to Islamize the economic system that already existed at the same time as a criticism of economic practices in Indonesia, such as banking and bank interest-based financial institutions that sparked debate among Muslim intellectuals (Choiruzzad and Nugroho, 2013).In studying the religion required a wide range of approaches to the substance of religion it is easy to understand. The approach here is a perspective or paradigm that is contained in a field of science that is then used in the understanding of religion. With this approach everyone can come to religion. From here it can be seen that religion is not just a monopoly among theologians and normalis, but religion can be understood by everyone in accordance with the approach and ability. Therefore, religion is the guidance given by God to humanity (Abdullah and Karim, 1990).

The reality encountered by humans in this life is divided into two. Firstly,Agreed reality that is everything that is considered real because we agreed designated it a reality; the reality experienced by other people and we acknowledge as a reality. Secondly, reality based on our own experience (experienced reality). Based on the two types of the reality, knowledge is divided into two kinds; knowledge acquired through the approval and knowledge gained through direct experience or observation. The first knowledge obtained by believing what others have to say because we do not learn everything through our own experience (Babbie, 1986). Science offers two kind approach to reality, both agreed reality and experienced reality, through personal reasoning, which is a special approach to discover that fact. Science offers a specialized approach called methodologies, the science to understand. 
In Islamic studies known several approaches used for understanding Islam. Among them is the normative theological approach, anthropological, sociological, psychological, historical, cultural, and philosophical approach. The approach here is not the approach in the context of the research, but the approach of point of view or paradigm that is contained in one field of science then used in the understanding of religion. In this connection JamaluddinRachmat said that religion can be studied using various paradigms of reality revealed religion has a truth value in accordance with the framework of its paradigm. Therefore, there is no problem whether the religious research includes as social science research or philosophical research (Abdullah and Karim, 1990).

Sharia Economics can be used as an approach in Islamic studies because the Sharia Economicshas basically beencombined between economic science and Islamic science (fiqhmu'amalah). Sharia Economics has two objects, they are formal object and material object. Formal object in Sharia Economics is all the production systems and distribution of goods and services by entrepreneurs both from the aspect of predictions of income as well as on the legal aspects of a transaction. While, the material object includes all the science related to the Sharia Economics science.

Furthermore, in order to understand Islamic studies using Sharia Economics can be done by several methods. There are, integrative and interdisciplinary methods.

\section{a. Integrative Method of Sharia Economics in Islamic Studies}

According to M. Amin Abdullah integrative approach is a combination of Islamic studies, normative and historically applied simultaneously and synthesis (Abdullah, 2012). The integration is a response to anxiety and criticism of each approach. Normative approach proponents criticize for example, as the reductions of the historical approach, while historical approach criticize the first approach as a rigid approach, closed and literalist.

MuhmmadAnasZarqa (2003) is one of the contributors of the update methods, especially in the Sharia Economics integrative approach. Zarqa studied about how to accomplice the integration between economics and Islam or how to form the Islamic Economic science.

In his methods he tried to find out how an economic system based on Sharia (Quran and Hadith). He separated the statements of Sharia and the economy into two categories, that is normative statements (prescriptive) and descriptivestatements (positive),then search for common ground between Islam statements (wahyu) and the economic statements, and replace the economic statements that is not in accordance with the Islamic statement (revelation)so from the whole process found the synthesis of sharia and the economy that create Sharia Economics.

The final result of the combination of economics and Islam is the establishment of sharia economics, which should consist of the following statements:

i. Normative statements and postulates of Islam (wahyu) and among its contents are legal provisions and rules of the Sharia economics system.

ii. Descriptive statements about Islam related to the economy (Nurcahyo, 2012). 
Zarqa explicitly tries to give effect to the general knowledge of Islam. Zarqa is also better positioning itself to argue that the integration of wahyu and $r a$ ' $y$ (sense and empirical experience) in Islamic jurisprudence move at different points, but met with the efforts of supporters of the thesis of this integration at the same point. Islamization of knowledge to integrate wahyu into scientific activities because the dimensions of this wahyu, the secular knowledge system has been set aside. In Islamic law, integration movement occurred otherwise, that is how to integrate human reasoninginto Islamic law methods, because this empirical dimension which have received less attention. Therefore, Zarqa (2003) states that in order to realize the connection and unification of Islamic assumptions and the contributions from Islamic heritage also the best achievements of the discipline at present by re-formulating the discipline from an Islamic perspective.Whereas, Waleed A.J. (2008) Addasexplains the purpose of Islamic economics is identifying and establishing and economic order that conforms to Islamic scripture and traditions.

\section{b. Interdisciplinary Method of Sharia Economics in Islamic Studies}

According to M. Amin Abdullah, interdisciplinary or interconnectivity is approaches are not mutually exclusive (atomistic), opposed (dichotomistic) or although applied simultaneously the model will not run itself, both parallel model and linear model. Interdisciplinary is an intensive interdisciplinary interaction between one or more disciplines, whether directly related or not, through research programs, with the aim of integrating the concepts, methods, and analysis (Prentice, 1990).

Interdisciplinary method is the approach in solving a problem by using a review of various viewpoints relevant cognate sciences in an integrated manner.Cognate science is science included in the same category that is Natural science, Social Science, or Cultural Science as an alternative. Moreover, relevant science is suitable science used in order to solve the problem. Whereas, integrated is the science used in solving a problem with this method is intertwined with one another implicitly that is a determination or unity discussions or description included in each description when discussing or describing it consist of descriptions (Kuhn, 1971).

From the explanation above, can be said that interdisciplinary approach means to understand Islamic studies by using several points of views in the study, such as sociological, historical and normative approaches simultaneously (Indera, 2007). Interdisciplinary is shown by integrating Islamic studies and social science (economy). In order to develop interdisciplinary approaches in Islamic studiescomprehension, the material of study should be approached from various sciences like economy, politics, law, and history.

The Sharia economics approach should ideally be integrative and interdisciplinary (integrative-interconnected in theory by M. Amin Abdullah). Normative approach 
through the interpretation of verses and hadiths regarding economy, which is applied integrative and interdisciplinary together with othersciences, forexample, linguistic, socio-linguistic, sociological, anthropological, and historical. Likewise, scientific approach when applied to assess social phenomena in the practice of economic activity in the community. This study should certainly be interconnected with a wide range of other scientific angle, such as theology, economics, social sciences, and so on. As can be seen in the image below:

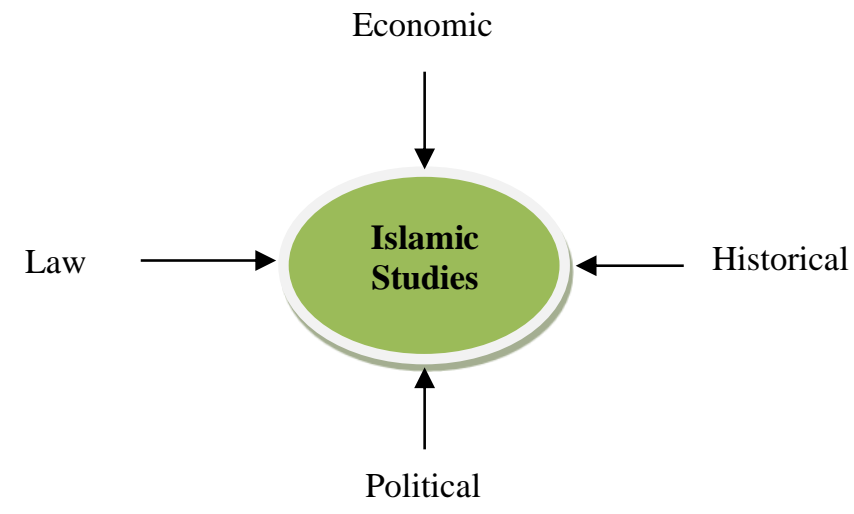

\section{Figure 1. The Development of Islamic studies from Various Approaches}

Based on the Figure 1 can be seen that Islamic studies using an economic approach could be an approach of its own to understand more about the study of Islam itself. Practice of mudharabah in the Sharia banks is one of the examples of the integrativeinterdisciplinary approach in Sharia economics. Mudharabah practice in ancient times can be found in the Quran and Sunnah. The relevance of mudharabah in ancient practice can be linked to the present condition of Sharia banks (phenomenology) and connected with other related disciplines. Essentially, the Islamic studies is an effort that is aspectual, polymethodic and pluralistic, where there are no strict limitations.Polymethodic in Islamic studies means that understanding of Islam by using various method or different disciplines. Therefore, Islam needs to be understood by the method of historical, sociological investigation, economic, and phenomenological. Islamic studies are pluralistic because there are many religions and traditions other than Islam (Permata, 2000).Both approach that has been described can be seen in the figure below:

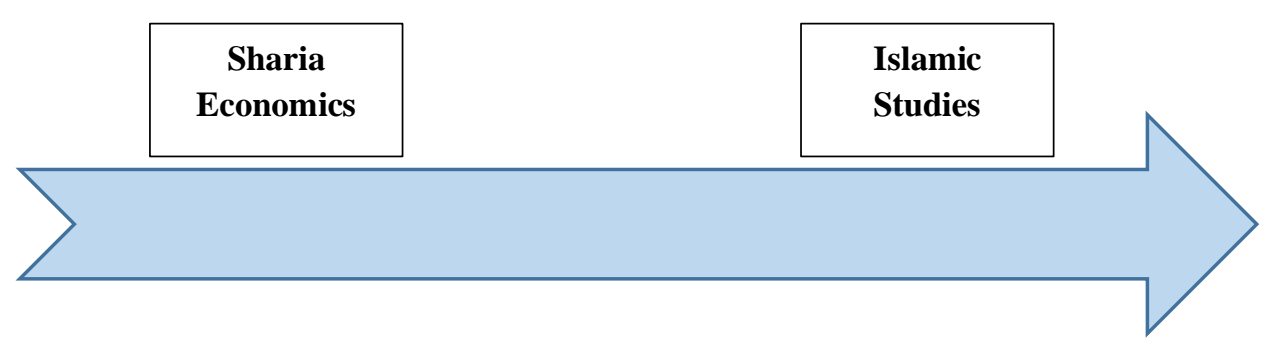




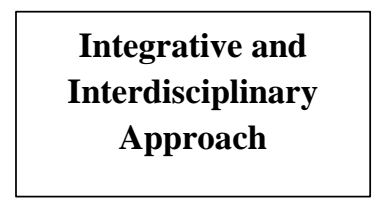

Figure 2. Sharia Economics Approach

The Sharia Economics as a one ways to understand Islamic studies needs integrative and interdisciplinary approach as a tool. Religion is expansion of economic values and social, religion can be a mechanism of economic integration. It is because theological dealing with something unknown and uncontrolled, and many other theories. Sharia economicsscience approach explains the empirical aspects of a person's religious norms of behavior as the influence of the economy and encouragement of halalanthayyibanmubarakan transactions for economic stability.TheSharia economics approach provides an explanation of the phenomenon of religionintegralization in economic. For that reasonsSharia economics can be used as an approach to understand the teachings of Islam. Thus, the existence of religion functionally can be felt by mankind easily if they know of such approaches (Nata, 2010).

The Sharia economic experts (MonzerKhaf, M. Abdul Mannan, MasudulAlamChaoudoury, and M. Fahim Khan) has formulated the Islamic economic methodology and agreed that leads to the teachings of Islam. Sharia economics method, can be simplified as follows (Kahf, 1989):

i. Sharia Economics formed based on wahyu that is Al-Qur'an and Al-Sunnah. The interpretation of the two sources must necessarily follow the guidelines set by the scholars venerated, not randomly (Manan, 1989).

ii. Sharia economics method preference is to use inductive method.

iii. Sharia economics built on noble values and ethics are based on Islamic law, such as the values of justice, simple, generous, and sacrifice. While based on Muhammad and Karim, universal values of Sharia economics consist of tawhid (oneness of God), al'adl (justice), nubuwwah (prophethood), khilafah (government), and ma'ad(result) (Saad and Karim, 1999).

iv. Study of Sharia economics is normative and positive.

v. Sharia economics aims to achieve falahin the world and hereafter.

\section{Integration between Economic Science and Islam}

Generally, religion is defined as human perception and beliefs associated with existence, the universe, and the role of God in the universe and human life so as to bring the relation patterns and behavior of human beings with God, with fellow human beings and the universe. Religion is a set of plans and behavior based on values, ethics and norms. Religion does not only related to spirituality and rituality, but also set of beliefs, rules and regulations as well as the moral of every aspect of human life.Religion from an Islamic perspective is as a way of life that is inherent in any human activity, whether related to 
God as well as those related to humans and the universe. Including the economic activity where there was interaction between mankind.

While the economy is generally defined as the study of human behavior in the use of scarce resources to produce goods and services that people need. Economy covers the field of human behavior associated with the consumption, production and distribution. The piety to God does not implicate in declining of economic productivity, instead bring a person to be more productive. Wealth can be closer to God when obtained in ways that conform with Islamic (halal and blessing).

Sharia economy built on the basis of Islam, therefore the economy that is based on sharia are an integral part of the rules of Islam (sharia) in its various activities. Islam is a way of life, where Islam has provided a complete regulation for human life. Most rules apply definite and permanent (qath'i) partly contextual (dhzonni) adjusted circumstances.

Islam as a religion based on the teachings of the Qur'an and Sunnah, gives many examples of the economic teachings such as, at the time of Prophet Ibrahim, Islam teaches people to donate. At the time of the Prophet Shuaib, Islam has taught that humans do justice in providing dosing, weighing properly and do not harm others. At the time of the Prophet Muhammad, Islam teaches that humans do honest and fulfill dose of scales when selling or buying goods. Here is a picture of the ideals of the Islamic teachings:

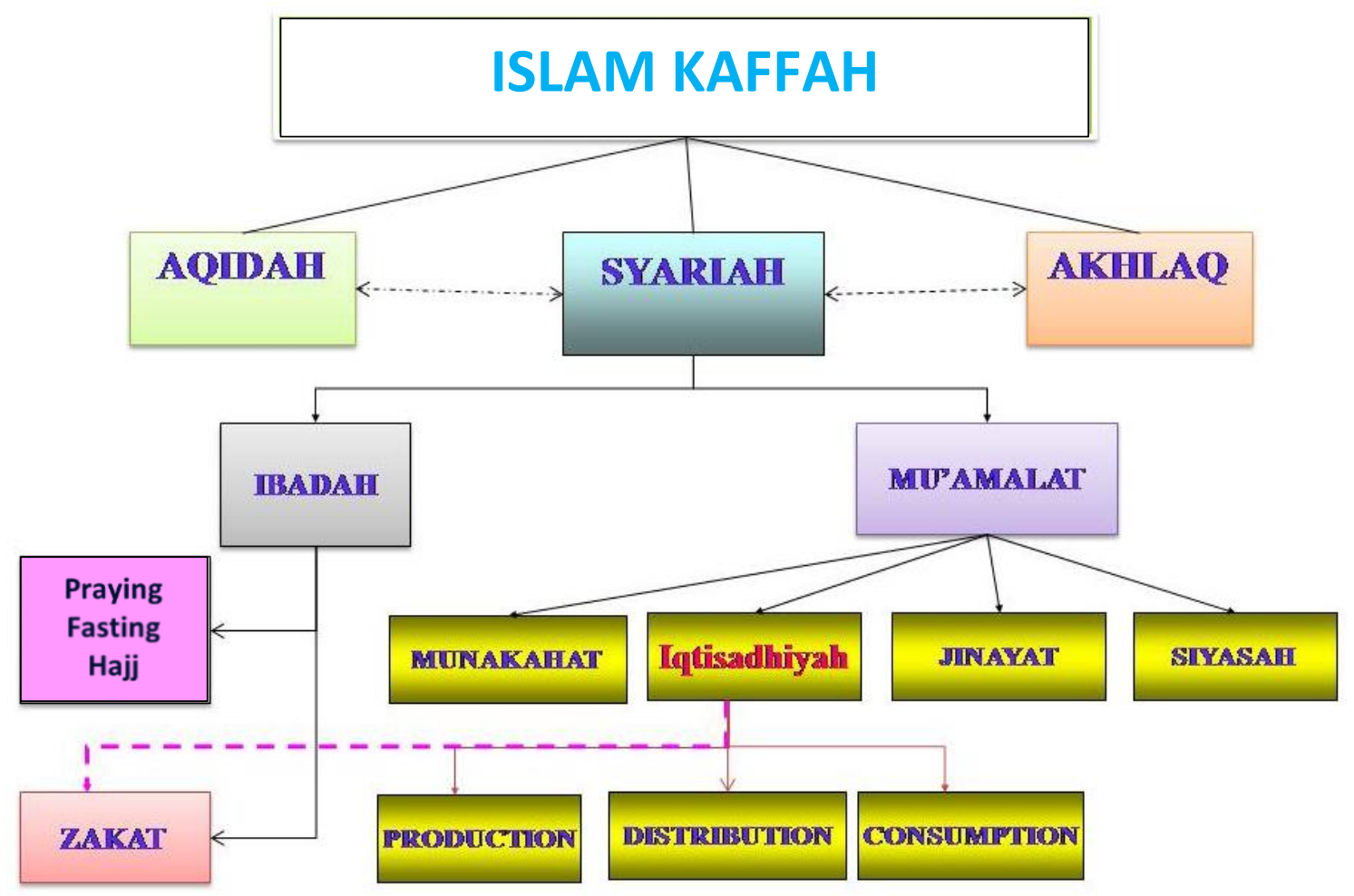

Figure 3. The Structure of Islam Kaffah

From the figure above, it can be seen that the implementation of Islamkaffah basically been giving out guidance on all aspects of human life.Islam kaffah means practicing Islam as a comprehensive system of human life, not just guidelines ritual 
between man and his God alone.Islam puts economic activities as one important aspect to get the glory (Falah). Falah will only be obtained if the teachings of Islam are fully implemented. Islam gives guidance on how to implement human life in society (mu'amalah).

The consistency and coherence between aspects of Islamic teachings in the form of union between beliefs, deeds and morality. Deeds (charity)are divided into two, namely, Ibadah (worship) and mu'amalah.Economic activity is part of mu'amalah and should be based on the true faith,thus it could generate the economic activity that moral or immoral.Islamic finance has become a manifestation of Islamic teachings in economic behavior, either from the economic activity goal setting, attitude, analysis, and response to social phenomena.

In the empirical level, the sharia economic behavior partially can be found in the group of the Muslims or non-Muslims. Ideal behavior as taught by Islam (in the Quran and Al-Sunnah) can actually be observed, then it is still believed to be a knowledge or science (P3EI, 2008).

\section{The Correlation of Sharia Economics with other Science in Indonesia}

Government intervention in Islamic administration in Indonesia has been running for a very long time (Alfitri, 2018).Based on the letter of Ministry of Education and Culture, Directorate General of Higher Education No. 0404 / E3.2 / 2015 on February 2, 2015, regarding the Revised General of Higher Education Decree No. 163 of 2007 of Arrangement and codification of Studies Program at the College and the Regulation Minister of Education and Culture No. 154 of 2014 on Cluster Science and Technology and Graduate Degree College, said that the Sharia economics for undergraduate has code of 6-1-3-04-23 and the Sharia Economic is belonging to the social sciences.

This indicated that the legalization position of sharia economics has clearly been recognized and regulated by the government through the Ministry of Education and Culture. Sharia Economics is the science or field of study that studies how humans make ends meet, according to the environment and his time, with the means or resources that are alternatives to achieve maslahah(Ghofur and Susilo, 2017). Because of sharia economics is the study of the behavior and the entire economic activity to reach Falah(fi ad-daroini au fi ad-dunyawa al-akhiroh) through a process that is halal and thoyyibbased on Quran and Sunnah (Adinugraha, 2013).

In detail, the sharia economic objectives can be explained as follows: a). Economic welfare is the most important economic objectives. Welfare includes the welfare of the individual, society and the country, b) Fulfilled the basic human needs, including food, drink, clothing, shelter, health, education, security and state systems that guarantee the adequacy of the basic needs in a fair, c) use of resources optimally, efficiently, effectively, economical and not redundant, d) Distribution of wealth, property, income and development results in a fair and equitable, e) To ensure the freedom of the individual, f) Equal rights and opportunities, g) Cooperation and justice (Zarqa, 1989). 
Based on the Directorate General of Higher Education, Ministry of National Education in 2012, relations between the Sharia economic science to other fields of sciencecan be explained that the combination of social science and religion science are actually deliveredto the field of sharia economics.Religion is a form of manifestation of responsibility to Allah, while social science is the embodiment of responsibility to family, community, and nation (Feisal, 1995). This is confirmed by the opinion of M. Abdul Mannan (1989) defines Islamic economics as a social science contain the Islamic values to study the economics problems of people.

Pragmatically, it can be said that economics is more materialistic oriented, while fiqhmu'amalat more focused on things that are normative. In other words, economics learning techniques and methods, while fiqhmu'amalat determines the legal status of whether may or not a business transaction. While from ontological side, sharia economics discusses the two disciplines simultaneously. Both disciplines it is pure economics and the science of fiqhmu'amalat. Thus, in operation sharia economics will always be sourced from these two disciplines (Rozalinda, 2015).

Moreover, when the sharia economics viewed in conjunction with other fields of science areeclectic and interdisciplinary fields of science, because of its history, sharia economics is the result of the convergence of knowledge of the various knowledge of sharia economics and conventional economics, sociology, politics, psychology and mathematics. Therefore, sharia economics is the study that highly relevant to the development of economic science in the world today, especially in Indonesia, sharia economics isthe refinement completeness of the economics of existing and gain enrichment from various disciplines that already exist.

The latest issue concerning the linkages and attachments between Islamic economics and other sciences is the need for synergy of the Islamic financial sector with information technology innovation for stakeholders now known as Sharia FinancialTechnology or Sharia Fintech (Mujahidin, 2019).Another synergy that needs to be carried out collaboratively by stakeholders iseducation intensity about halal lifestyle (Indonesia Islamic Economic Masterplan 2019-2024).

\section{CONCLUSION}

Sharia Economics is derived of mu'amalah established based on sharia and Islam which is always rooted on the Quran dan Al-Sunnah.Therefore, sharia economics is an integral part of the sharia rules. In terms of ontology, sharia economics discusses the two disciplines simultaneously, namely the integration of the discipline of economics and the science of religion (more specifically, is fiqhmu'amalat). It aims to facilitate the understanding of Islamic studies. One approach that was developed for the study of Islamic studies is sharia economics.Sharia economics provide an explanation of the phenomenon of integralization religion in economics to understand Islamic studies. Sharia economics explains the empirical aspects of a person's religious as an influence of economic behavior norms and boost of blessing transaction for economic stability.Ideally, 
the Sharia economics approach should be integrative and interdisciplinary (integersinterconnected). Integrative method seeks to combine the wahyu and $r a$ 'y in economic studies to understand Islam from the economic aspect. While the method of interdisciplinary or interconnected attempt to approach with a wide range of disciplines such as economics, politics, law, and history, so it produces a comprehensive study and relevant to the facts/phenomena.

\section{REFERENCES}

A. A, Muhammad., and Karim, AdiwarmanAzhar. (1999). Sisitem, Prinsip, danTujuanEkonomi Islam. Translate by Imam Saefuddin. Bandung: PustakaSejati. 
Abdullah et.all. (1990). MetodologiPenelitian Agama SebuahPengantar. 2nd ed. Yogyakarta: Tiara Wacana.

Abdullah, M. Amin. (1996). Studi Agama NormativitasatauHistorisitas.1st ed. Yogyakarta: PustakaPelajar.

(2012). Islamic Studies di PerguruanTinggi: PendekatanIntegratifInterkonektif. Yogyakarta: PustakaPelajar.

Abdullah, Taufik., and Karim, M. Rusli. (1990). MetodologiPenelitian Agama SebuahPengantar. 2nd ed.Yogyakarta: Tiara Wacana.

Addas, Waleed A.J. (2008). Methodology of Economics: Secular vs Islamic. Malaysia: International Islamic University Malaysia Press.

Adinugraha, HendriHermawan. (2013). "Norma danNilaidalamIlmuEkonomi Islam". Jurnal Media Ekonomi\&TeknologiInformasi. Vol. 21. No. 1.

Alfitri. 2018. "Religion and Constitutional Practices in Indonesia: How Far Should the State Intervene in the Administration of Islam?". Asian Journal of Comparative Law. 13.

Anwar, Rasihon., and Badruzzaman. (2009). PengantarStudi Islam. Bandung: PustakaSetia.

Babbie, Earl. (1986). The Practice of Social Research. California: Wadasworth Publishing Co.

Biro HukumdanOrganisasiKemendibud. (2014). Regulation of Minister of Education and Culture Republic of Indonesia No.154/2014.Jakarta: Minister of Eduation and Culture.

Byarwati, Anis., and Sawarjuwono, Tjiptohadi. (2013). "Ekonomi Islam atauIqtishad?".JurnalEkonomi, ManajemendanAkuntansi Islam I M A N E N S I. Volume 1. No. 1.

Choiruzzad, Shofwan Al Banna and Bhakti Eko Nugroho. 2013. "Indonesia's Islamic Economy Project and The Islamic Scholars". Procedia Environmental Sciences. 17.

Daulay, Haidar Putra and Tobroni. 2017. "Islamic Education in Indonesia: A Historical Analysis of Development and Dynamics". British Journal of Education. Vol. 5. No. 13.

DirektoratJenderalPendidikanTinggiKementrianPendidikanNasional.

NamaRumpunIlmu, Sub RumpunIlmudanBidangIlmudalamRumpun. Jakarta: Minister of Education and Culture.

Fairclough, Norman. 1995. Critical Discourse Analysis: The Critical Study of Language. Feisal, Jusuf Amir. 1995. ReorientasiPendidikan Islam. Jakarta: GemaInsani Press. 
Ghofur, Abdul and Susilo, Sulistiyono. (2017). "Maslaha as the Philosophical, Political, and Legal Basis on the Islamic Banking Legislation in Indonesia”. Global Journal Al Thaqafah. Vol. 7. Issue. 1.

Hamdi, Rahman; Sauri, Sofian; Halim, Mohd Zahirwan; Hassan, Paiz; Yusri, Muhammad. (2017). "Aplikasi Pemikiran Islam dalam Pendidikan Sains the Application of Islamic Thought in the Teaching of Science". Global Journal Al Thaqafah. Vol. 7. Issue. 1.

Hoetoro, Arif. 2007. Ekonomi Islam, PengantarAnalisisKesejarahandanMetodologi. Malang: BPFE Unibraw.

Indera. 2007. "IntegrasiSejarahdanIlmu-IlmuSosialdalamPemikiranFurnandBraudel”. HISTORISME. No. 23.

Indonesia Islamic Economic Masterplan 2019-2024

Kahf, Monzer. 1989. "Islamic Economics and Its Methodology"in AiditGhazali and Syed Omar (eds.). Readings in The Concept and Methodology of Islamic Economics. Petaling Jaya: Pelanduk Publications.

Kuhn, Thomas S. 1971. The Structure of Scientific Revolutions. Chicago: University of Chicago Press.

Mannan. M. Abdul. 1986. Islamic Economics; Theory and Practice. Cambridge: Houder and Stoughton Ltd.

Nasr, Syed Husen. 1995. MenjelajahDunia Modern. (translate) HastiTarekat, from A Young Muslim's Guide in The Modern World. 2nd ed.Bandung: Mizan.

Nata, Abuddin. 2010. MetodologiStudi Islam. Jakarta: PT. RajaGrafindoPersada.

Nurcahyono. Moh. Lutfi. 2012. "PembaruanMetodePenemuanHukum Islam: PendekatanTerpaduHukum Islam dan Sosial”. UlumunaJurnalStudiKeislaman. Volume 16. No. 1.

P3EI. 2008. Ekonomi Islam. Jakarta: PT RajaGrafindoPersada.

Permata, Ahmad Norma. 2000. MetodologiStudi Agama. Yogyakarta: PustakaPelajar.

Praja, Juhaya S. 2002. FilsafatdanMetodologiIlmudalam Islam danPenerapannya di Indonesia. Jakarta: Teraju.

Prentice, A.E. 1990. Information Science - The Interdisciplinary Context. NewYork: Neal-Schuman Publishers.

Rokhzi, Mokh. Fatkhur. 2015. "PendekatanSejarah dalam Studi Islam". ejournal.kopertais4.or.id. Vol. III. No. 1.

Rozalinda.

2015.

"EpistemologiEkonomi

Islam danPengembangannyapadaKurikulumEkonomi Islam di PerguruanTinggi”. Human Falah. Volume 2. No. 1. 
Sumardi, Mulyanto. 1982. Penelitian Agama. Jakarta: SinarHarapan.

Turban, E., King, D., Lee, J., Liang, T., Turban, D. 2015. Electronic Commerce a Managerial and Social Networks Perspective. Eighth Edition. New York: Springer Cham.

Zarqa, Muhammad Anas. 1989. "Islamic Economics: An Approach to Human Welfare", in AiditGhazali and Syed Omar (eds.). Readings in The Concept and Methodology of Islamic Economics. Petaling Jaya: Pelanduk Publications. 2003. "Islamization of Economic: The Concept and Methodology". J.KAU: Islamic Economy. Vol. 16. No. 1. 